\title{
ISLAMIC CHARACTER DEVELOPMENT THROUGH BOARDING-BASED PUBLIC SCHOOLS: INTERNALIZATION ISLAMIC METHODS
}

\author{
Nur Rizqi Febriandika 1 ) * \\ Chori Miftahul Kosidatul Natus ${ }^{2)}$ \\ 1,2 Universitas Muhammadiyah Surakarta. \\ *E-mail:nrf679@ums.ac.id
}

\begin{abstract}
This study aims to explain and identify the methods used in internalizing Islamic characters in boarding-based public schools. Public schools that implement a boarding system have a unique and special character. It is different from Islamic education which has been firmly embedded in schools that have been based on pesantren since beginning. This research is descriptive qualitative, with data collection methods through observation, interviews, and documentation. The results of this study show that internalization of Islamic characters through subjects in the dormitory, such as the study of classical Islamic books (Fiqhu Sunnah, Aqidatul Awwan, Bidayatul Mujtahid, etc) and self-development activities in the form of extracurricular and organizational activities. The used methods are the wisdom method, exemplary method, habitual method, mauidzah method and the reward and punishment method. Unlike pesantren culture which is closely tied to the figure of the kyai, the dormitorybased State Islamic schools tend to be weak in terms of the initiative and charisma of the kyai who are the leaders. Individually, kyai figures in boarding-based public boarding schools do not have as strong a role as those in pesantren. However, the ustad and coach figures play a collective and joint role in building students' Islamic character.
\end{abstract}

Keywords: Islamic Character, Madrasah Aliyah, Boarding System, Public Schools

\begin{abstract}
Abstrak
Penelitian ini bertujuan unutuk menjelaskan dan mengidentifikasi metode apa saja yang digunakan dalam internalisasi karakter islami di sekolah Islam negeri berbasis asrama. Sekolah negeri yang menerapkan sistem asrama memiliki karakter yang unik dan khusus sehingga berbeda dengan pendidikan Islam yang sudah tertanam kuat di sekolah yang sejak awal berbasis Pondok Pesantren (pesantren). Penelitian ini bersifat deskriptif kualitatif, dengan metode pengumpulan data melalui observasi, wawancara, dan dokumentasi di MAN 1 Surakarta Program Keagaman. Hasil penelitian ini adalah: pertama, internalisasi karakter islami melalui mata pelajaran di asrama, seperti kajian kitab klasik (Fiqhu Sunnah, Aqidatul Awwan, Bidayatul Mujtahid, dll) dan kegiatan pengembangan diri berupa ekstrakurikuler dan organisasi. Kedua, metode yang digunakan adalah metode hikmah, metode keteladanan, metode pembiasaan, metode mauidzah, metode reward dan punishment. Berbeda dengan kultur pondok pesantren yang terikat erat dengan sosok figur kyai, sekolah Islam Negeri berbasis asrama cenderung lemah dari sisi inisiatif dan karisma kyai yang menjadi pemimpinnya. Secara individu, figur kyai di sekolah Islam negeri berbasis asrama tidak memiliki peran sekuat sosok kyai di Pondok Pesantren. Walaupun demikian, figur ustad dan pembina berperan secara kolektif dan bersama-sama dalam membangun karakter islami siswa.
\end{abstract}

Kata kunci: Karakter Islami, Madrasah Aliyah, Sistem Asrama, Sekolah Negeri 


\section{INTRODUCTION}

Character can be interpreted as value education, character education, moral education, character education, which aims to develop the ability of students to make good and bad decisions, maintain goodness, manifest and spread goodness in daily life. Character is clearly of general human importance. Its deliberate or explicit promotion may not be equally warranted in all educational contexts (Fitria, Kristiawan, \& Rasyid, 2019). Making students with a character is the task of education, the essence of which is to build a whole person, namely a good human being and character (Setiawati, 2017).

The National Education System states that national education functions to shape the personality of students, develop the potential of students by developing their morals (Komara, 2017). National education aims to make human learners who are not only good at cognitive, but also good morals and behavior It can be interpreted that character education and education in general have the same function and purpose, namely forming a good character or personality (Febriandika, Gaida, 2021).

The main purpose of character is to develop knowledge, attitudes and skills in a balanced manner (Cornelissen et al, 2020). Our education has provided a very large portion of knowledge, but forgets the development of behavioral values or attitudes in learning. The subject matter given is quite a lot, but in practice it is less embedded in the attitudes and behaviors of the students, because learning only comes to knowledge, not yet contained in their soul (Fauzan, 2013).

Each educational institution has its own way of developing the potential of students to become human beings who excel in academics and students with character (Kamenez et al, 2018). Therefore, educational institutions are the right place for development, guidance, direction for students. It is expected that education can combine 3 elements of education, namely, cognitive, attitudes and skills.

The role of religion in character is important which religion has a great influence in the formation of character of students, especially Islamic characters (Budiman \& Idris, 2018). Therefore, the internalization of Islamic characters is not enough, if only given in formal learning because only the material that students can, but the internalization of Islamic characters is also given outside formal learning. Through activities that can develop character and add to the treasures of Islamic students. So that it can be contained in daily life positive behavior reflected in religious teachings. 
Educational institutions that implement a boarding system which is not entirely like pesantren internalization of Islamic character is considered quite influential on students. The boarding system education is not solely for enrich the student's mind with explanations, but also to increase moral, enhace the spirit, respect spiritual values, and teach attitudes and behavior. Other than that, for prepare the students to be taught about religious ethics above oyher ethics (Prasodjo, 1974).

Boarding education aims to improve student's morals (Parker, 2019). Morals as the basis is a reflection owned by someone. If the character is good, then in itself a person it has good morals. Conversely, if someone has bad character, then he has bad morals too. Morals is the main basis in the formation of a person or human character completely (Krettenauer, 2021). Education that leads to the formation of moral personality is the first thing that must be done, because it will underlie stability of human personality and faith as whole (Alwi, 2014).

Based on observation of the background of the problems that have been carried out by researchers that Madrasah Aliyah Negeri 1 Surakarta the Religious Program is one of the formal institutions under the auspices of the Ministry of Religion. In this school the author sees an interesting thing, namely Islamic character is not only done during school hours, but the process of developing Islamic character is also carried out in the boarding system. The existence of a boarding is very important for the formation of character in the Madrasah Aliyah Negeri 1 Surakarta Religious Program, especially the Islamic character. Through Islamic activities such as studies, religious practices such as congregational prayers, tahfidz programs, and yellow book studies, which all activities have been systematically programmed.

The purpose of this study is to answer the problems formulated by researchers; first, to describe the process of internalizing Islamic character education through a boarding system at Madrasah Aliyah Negeri 1 Surakarta Religious Program. Second, to identify the methods used in Islamic character education through a boarding system at Madrasah Aliyah Negeri 1 Surakarta Religious Program. The difference between this study and previous research is the research location at general school that can be used as means of internalizing Islamic character. The school that use a boarding system using various methods of internalizing Islamic character. 
In describing the problem formulated, reserchers used a phenomenological qualitative approach. To be able to obtain data that is relevant to the issues discussed, the authors use several methods, namely: Observation Method, Interview Method, Documentation Method. Data analysis in this study used qualitative data analysis. Activities in data analysis are; reduction, display and conclution. The first step of reduction, which is sorting data from interviews, observations and documentations. The second step, display, which is presenting data in the form of narration or paragraph and the last conclusions, namely drawing conclusions from all the problem formulas in the study.

\section{RESEARCH METHODS}

1. Types of Reaserch

This research includes field research qualitative, namely research that aims to collect data and information based on phenomena that occur in real life where researchers get it from objects and research subjects in real and direct. The approach used in this study is a qualitative approach that is collecting and analyzing data in the form of words (oral and written) and human actions and the researcher does not attempt to calculate or quantify the qualitative data that has been obtained and thus not analyze the numbers (Afrizal, 2016).

2. Research Time and Place

The research began at the beginning of October and the research was completed at the end of December. This research was conducted in one of the educational institutions in the city of Surakarta, namely in the boarding of Madrasah Aliyah Negeri 1 Surakarta Religious Program. The reason the researchers conducted the research in this place was because the topic of the discussion was very relevant to the activities in the Madrasah Aliyah Negeri 1 Surakarta Religious Program.

3. Research Subjects

The source of the information obtained, in this case the subject of the research, was Mr. Luqman as the head of the religious program, Mrs. Luluil as the female boarder, Mrs. Taslia as the boarder, Mr. Mundzir as the facility and infrastructure, Mr. Abdul Mutolib as the boarding chair and Nilna Dzati Layyinah as Secretary of the Religious Program Student Organization. 


\section{RESEARCH PROCEDURE}

1. Data Collection Technique

To be able to obtain data that is relevant to the issues discussed, the authors use several methods, namely:

a. Observation

Observations carried out in this study are direct observations of the source of information, namely through data and also activities that can foster student character. Observation is done by observing directly when the teaching and learning activities take place and also observing the activities in the student dormitory. This method was carried out to obtain data relating to the Internalization of Islamic Characters through the Boarding System in Madrasah Aliyah Negeri 1 Suarakarta Religious Program.

b. Interview

Interviews are a form of verbal communication, a kind of conversation that aims to obtain information. In interviews questions and answers are given verbally. This method is used to find out and obtain data through direct information that can be obtained from, Mr. Luqman as the chairman of the religious program, Mrs. Luluil as the female boarding coach, Mrs. Taslia as the female boarder coach, Mr. Luqman as the head of the religious program, Mr. Abdul Mutolib as the boarding chair, Mr. Mundzir as part of the facilities and infrastructure and Nilna Dzati Layyinah as Secretary of the Student Organization Program on the Internalization of Islamic Characters through the System of Madrasah Aliyah Negeri 1 Surakarta Religious Program. Therefore the researcher will interview various sources related to the discussion above.

c. Documentation

Documents are a means of assisting researchers in collecting data or information by reading letters, announcements, meeting summaries, written statements of certain policies and other written materials (Sarwono, 2006). The documentation method in this study was used to collect data, namely: the history of the establishment of Madrasah Aliyah 
Negeri 1 Suarakarta Religious Program, organizational structure, number of santri, number of teachers and employees, facilities and infrastructure.

2. Data Analysis Method

Data analysis in this study used qualitative data analysis. Data analysis is carried out from the data collection stage to the report writing stage. Therefore, data analysis in qualitative research is referred to as continuous analysis. Qualitative data analysis is done by working with data, organizing data, selecting it into manageable units, synthesizing it, finding and finding patterns, finding what is important and what is being learned, and deciding what is important and what is learned, and decide what can be told to others (Ghony \& Almanshur, 2017).

Activities in data analysis are, reduction, display and conclution. The first step of reduction, which is sorting data from interviews, observations and documentations. The second step, display, which is presenting data in the form of narration or paragraph and the last conclusions, namely drawing conclusions from all the problem formulas in the study.

\section{RESULT}

\section{Internalization of Islamic Character Through the Boarding School}

Generally, the character is interpreted as the inner nature of man who influences all thoughts and actions, and means tabi'at, and manners (Utaminingsih, Utomo, \& Zamroni, 2017). Furthermore, if there is an expression of character education, then what is meant is an effort to influence all thoughts with certain inner characteristics, so that they can form character, character, and have personality. Whereas what is meant by nature is the appearance and condition of things. Furthermore, the word education in general is an effort to influence others to change their mindset, speech, actions, character and character according to their intended goals. Therefore. Between the word education with the word character becomes near the substance (Nata, 2012).

The character includes three main elements, namely knowing the good (knowing the good), loving kindness (Desiring the good), and doing good (doing the good). In line with Lickona, Frye defines character education as "A national movement creating schools that are ethical, responsible, and caring young people by modeling the teaching of good characterization and emphasis on universal values that we all share" (Suyadi, 
2013). In the context of Islam character or commonly referred to as "moral" or morality in Islam has existed since Islam existed because of the sending of the Prophet Muhammad on this earth to perfect morals. In this Islamic perspective, the foundation of morality of students in Islamic education will be rebuilt in order to grow into a noble human being, who benefits other creatures (Muhsinin, 2017).

The Ministry of National Education has formulated 18 character values that will be instilled in students as an effort to build national character. The following will be presented by 18 Ministry of National Education version character values as set out in the National Character and Culture Education Development book prepared by the Ministry of National Education through the Research and Development Center for Curriculum Centers (Ministry of National Education, 2010): (1) Religious, (2) Honest, (3) Tolerance, (4) Discipline, (5) Hard Work, (6) Creative, (7) Mandiri, (8) Democracy, (9) Curiosity, (10) Nationalism and Nationalism, (11) Love of the Motherland, (12) Respecting Achievement, (13) Communicative, (14) Love Peace, (15) Loving Reading, (16) Environmental Care, (17) Social Care, (18) Responsibility (Suyadi, 2013). In the character design of the Ministry of National Education of the Republic of Indonesia, it is said that character is a process of civilization and empowerment of noble values in the environment of the education unit (school), family environment, and community environment (Johansyah, 2011).

Islamic character is all the contents contained in character education contained in the regulations issued by the Indonesian Ministry of Education (Husni, 2020). Only religious content is given more portion in its discussion and the emphasis in Islamic character by expanding the scope of the Godhead value. Character education has relevance to strengthening the character values taught by the Islamic religion, in which there are teachings or practices that teach humans to carry out religious teachings and do good for all humans (Arifin, 2019).

Character is an unavoidable goal of the world of education (Sanusi, 2013). It can be concluded that character e has the following objectives; Strengthening and developing the values of life that are considered important and necessary so that they become the distinctive personality / ownership of students as the values developed, correcting student behavior that does not correspond to the values developed by the school, Establish connections that are in harmony with family and society in acting out the responsibilities of character education together (Sahlan, 2019). 
Internalization of Islamic character is an in-depth business process in understanding religious values combined with whole values whose goal is to unite in the personality of learners. There are several ways to implement the internalization of Islamic characters at MAN 1 Surakarta:

a) Through Subject

Through its own subjects, such as Islamic Education and Citizenship Education. Meanwhile, it is integrated into all subjects meaning through all existing subjects. Character values can be integrated in teaching material or through a valid learning process.

b) Through activities outside the lessons and self-development activities

The point is the character formation of students through all activities outside of learning commonly referred to as extracurricular activities in the form of habituation-habituation of noble moral values in it, such as IMTAQ activities, Al-Qur'an tadarus, and scouts.

c) Through Reward and Punishment

Reward is giving gifts as incentives for students or children to be motivated to do good or noble character, while punishment method is giving sanctions as a deterrent effect for students or children not to dare to do evil or violate applicable regulations.

d) The Role of Boarding Coach in Internalizing Islamic Character

Islamic educators / boarders are holders of the control of the educational process directed at the goal of Islamic education, which is more concerned with the process of creating an educational atmosphere that encourages effectiveness that is more important in the process of creating an educational atmosphere that encourages the effectiveness of the learning process (Arifin, 2000).

Boarding coaches also play a role as mentors, namely providing assistance to individuals to achieve understanding and self-direction needed to make maximum adjustments to schools, families and the community (Ilyasin, 2020). In the whole process of teacher education is the main factor (Hamalik, 2009).

One of the places that is conducive to improving student character is a school that has a boarding system. The boarding is a place to live for children where they are given 
teaching or attending school (Abidin, 2014). In the boarding students attend regular education from morning to afternoon at school then continue with religious education or special values education at night. For 24 hours students are under the education and supervision of the supervising teachers. The values taught in the dormitory in order to establish a mature personality essentially lead to all the values of the nation's educational character, as for the basic values implemented in the hostel based on $\mathrm{Al}$ Qur'an and As-Sunnah (Wati, 2017).

\section{Islamic Methods to Improve Islamic Character}

There are several methods that are often applied in developing children's character (Hussin \& Tamuri, 2019). The method in general must be applied in accordance with the conditions and situations faced. Often an educator (teacher or parent) must implement several methods in an integrated manner, such as inviting children to think wisely and giving examples of wise behavior. In general, the character attemps to character?), Behave (for example, animating good behavior and absorbing it in the heart), and acting (for example, implementing good actions) (Abdullah \& Muhammad, 2016). Here are some methods that can be applied in developing a child's character:

a) Qishah Method (Story)

This method is a way delivery or presentation of material deep oral learning form the story from the teacher ti the student. In this implementation activities, this method implemented to introduce, deliver description, or an explanation of new things in order convey develop a variety basic competencies (Tambak, 2016).

In Madrasah Aliyah Negeri 1 Surakarta Religious Program has no qishah method. The qishah method in this school merges into one in the hikmah method. In the hikmah method students are given a review of events that occurred in the past and present and then the teacher took lessons from the event. take lessons from every event experienced by humans to know the essence of an event witnessed, noticed, so that the conclusion can affect the heart to submit to Allah. This principle is carried out through stories, paying attention to natural phenomena, or events that have occurred both in the past and now through a process of critical and deep reflection. 
b) Exemplary Method

In planting Islamic values to students, exemplary is a more effective and efficient method. Because students in general tend to emulate (imitate) the teacher or educator. Because psychologically students like to imitate, not only good but also bad. Allah SWT has made His Messenger as an example for every Muslim, both the person who is in his day or afterwards (Al-Ahzab: 21). The essence of exemplary is imitation, which is the process of imitating students towards teachers, the imitation that children do with adult, the imitation process that is done by children to their parents, and that in exemplary happens the imitation process (Munawaroh, 2019).

Exemplary is education by providing real examples for students. Ma'had Hadil Iman's manager strives to always set a good example for students in their daily lives. As Ustad Abdul Mutolib said:

"The teacher is a role model for his students, of course, he must exemplify the good things as exemplified by the Prophet. The nature of the child is to imitate the teacher, so, the child prioritizes his vision rather than his hearing, meaning that what they see is faster to imitate than what they hear and as a teacher not only advise, but also do it with action".

c) Habitual Method

The habituation is the process of forming new habits or improving habits tha has been there. Habits other than using commands, role models, and special experiences, also use punishment and reward. The goal is that students acquire attitudes and new habits that are more precise and positive in the sense that they are in tune with needs space and time (contextual). In addition, the precise and positive meaning is in accordance with norms and prevalling moral values, both religious and traditional and cultural (Ahsanulhaq, 2019).

In the dormitory life students are trained to get used to a structured lifestyle. Daily activities in the dormitory are a form of integration between the head of the dormitory, boarding boarders and Religious Program Learning Organizations (OPPK). As stated by Ustad Mundzir:

"The coach as a facilitator, to make children's activities more effective, yes they are also representatives of parents, later the coach who evaluates the performance of OPPK, from the head of the school, goes 
to the head of the dormitory, then to the Trustees and then goes to OPPK".

To prepare a characteristic personality, students are trained to get used to acting obediently to the norms that apply in everyday life. This principle is applied in the form of regularity of life which is regulated in a daily activity schedule that starts from early morning to evening rest. Daily activities include worship / prayer both personally and jointly, eating together, learning together, maintaining comfort and other activities programmed in the whole process as long as students are educated in Madrasah Aliyah Negeri 1 Surakarta Religious Program.

d) Mauidzah Method (Advice)

Mauidzah hasanah consists of two words "al mauidzah and hasanah". Al mauidzah in etymological review it means "pitutur", discourse, teaching, education, while hasanah mean good. When these two words are combined it means teaching the good one. Ibn Katsir interpets al mauidzah hasanah as giving warnings to humas, preventing and staying away from prohibitions so with this process they will remember Allah (Al Syarif \& Manshur, 2017).

Advice is giving a warning of goodness and truth in a certain way that can touch the heart to practice it. This principle also gives a mandate to students to have the attitude of receiving advice and reminding each other of good things among fellow residents of Ma'had. As Ustad Abdul Mutolib said:

"As teachers we often give advice or some kind of advice, every day we convey it, every time we enter the lesson. His name is also living together in a hut, they must respect, their fellow human beings must know, well, we convey it with advice, also with children who are sometimes rather problematic, we also call upon us to give advice ".

e) Reward and Punishment

Rewarding is a form of appreciation for students who excel, not only in academics, but in other cases such as therapy rooms, therapy cabinets, or students who have the least violations in the dormitory. Likewise, in terms of giving punishment or punishment. For students who violate will be given sanctions in accordance with the mistakes made. Starting from mild, moderate and severe errors each has its own sanctions. For minor errors 
and some errors in the light sanction category, the security department for security budgeting and the language department for language circulation.

For serious violations such as smoking, promiscuity, etc., the sanctioners are boarders. Provision of sanctions is not in the form of severe physical punishment, but educative punishment or educative punishment, such as memorizing letters, forgiving Mufrodat and so on.

\section{DISCUSSION}

The Internalization Process of Islamic Character Education through the Madrasah Aliyah Negeri Surakarta 1 Boarding System Religious Program consists of several ways such as through boarding curriculum. Boarding curriculum Madrasah Aliyah Negeri 1 Surakarta Religious programs are integrated with the school curriculum. Madrasah Aliyah Negeri 1 Surakarta uses a curriculum that has been implemented by the government, namely the 2013 curriculum (kurtilas), in which all aspects have their own values both from the cognitive, affective, psychomotor and spiritual domains. In addition to following the government in the implementation of the 2013 curriculum, the Aliyah Madrasah Religious Program has a proportion of 70\% curriculum subjects and $30 \%$ general subjects. From the proportion of the curriculum, $70 \%$ of religious subjects are expected to have truly broad knowledge of Islam. While $30 \%$ of general subjects are expected to be able to support in studying religion in relation to general science that is currently developing.

There are two learning methods that applied in the Madrasah Aliyah Negeri 1 Surakarta Religious programs, namely learning in school (class) and learning in the boarding. Learning in school consists of morning learning and afternoon learning. Morning learning, namely the process of teaching and learning activities in the school takes place from the morning at 07.00 and learning activities (ends at 3:00 p.m. After the end of the activity in the morning at 3:00 p.m., the activity continued with afternoon learning, namely the tutorial. In the tutorial lessons are taught in the form of lessons to support students' understanding and mastery of the Arabic language, for example shorof, nahwu, balagoh, and so on.

There are many programs available at Madrasah Aliyah Negeri 1 Surakarta boarding Religious Program that can support student's Islamic character education. The boarding at Madrasah Aliyah Negeri 1 Surakarta Religious Program is a cottage so 
all the programs contain Islamic elements. In the morning lesson, a lot of material about the character of Islam and the boarding has become a place for strengthening that character. One of the character reinforcement material in the dormitory is a book study such as Ta'lim Muta'alim.

All students are required to obey all regulations that have been set in the dormitory. For students who do not obey the rules will be penalized according to the mistakes made. In this case, it is intended to make students have an attitude of obedience to the prescribed rules. Discipline will encourage students to be able to respect each other, ensure the comfort of the students, so that the life in the hostel takes place harmoniously. The sanctions applied in the dormitory are educational and not in the form of physical punishment. All members of the Religious Program Student Organization (OPPK) which oversees all the rules and regulations of the hostel are assisted by all rayon administrators in the success of the joint order.

Unlike pesantren culture which is closely tied to the figure of the kyai (Alam,2020), the dormitory-based State Islamic schools tend to be weak in terms of the initiative and charisma of the kyai who are the leaders. A leader is needed to create a vision and all the individual components associated with educational institutions (Nasir, 2010). Individually, kyai figures in boarding-based public boarding schools do not have as strong a role as those in pesantren. However, the ustad and coach figures play a collective and joint role in building students' Islamic character.

Besides that, there are also programs that can be used by students as a means of self- actualization, such as organization and extra-curricular activities. At the Madrasah Aliyah Negeri 1 Surakarta Religious Program there is an organization run by students of the Religious Program namely OPPK (Religious Program Student Organization). The organization that became the forum for the students of the Religious Program was born in 1992, one year after the birth of the Madrasah Aliyah Negeri 1 Surakarta Religious Program. Religious Program Student Organization (OPPK) as an extension of the IntraSchool Student Organization (OSIS). Whereas Intra-School Student Organizations (OSIS) are general organizations in Madrasah Aliyah Negeri 1 Surakarta Religious Program and Student Organizations Religious Programs (OPPK) are organizations that are specific to child religious programs. Student Organizations Religious Programs (OPPK) help with coaching such as congregational prayers, language enhancements 
and so forth. In addition to assisting the duties of the Trustees, the Religious Program Student Organization (OPPK) is also a forum for organization and self-actualization.

There are several extra-curricular activities, student extracurricular activities consist of activities that accommodate students' interests and talents including Scouts, Firqoh Calligraphy Al-Hasyimi, Hadrah, Tilawatil Qur'an, and Youth Scientific Work. Extracurricular activities at Madrasah Aliyah Negeri 1 Surakarta Religious programs are semi-autonomous santri organizations, namely organizations formed by santri to develop certain interests. Some og the things that have been mentioned above are positive activities that are expected to be a means to develop student character and of course will always be improved for better.

\section{CONCLUSION}

Based on the findings and discussion of this study, it can be concluded that this research show about internalization of Islamic characters through subjects in the dormitory, such as the study of classical Islamic books (Fiqhu Sunnah, Aqidatul Awwan, Bidayatul Mujtahid, etc) and self-development activities in the form of extracurricular and organizational activities. The used methods are the wisdom method, exemplary method, habitual method, mauidzah method and the reward and punishment method.

Unlike pesantren culture which is closely tied to the figure of the kyai, the dormitory-based State Islamic schools tend to be weak in terms of the initiative and charisma of the kyai who are the leaders. Individually, kyai figures in boarding-based public boarding schools do not have as strong a role as those in pesantren. However, the ustad and coach figures play a collective and joint role in building students' Islamic character.

\section{SUGGESTION}

Based on the results of research and conclusions that have been described, there are several suggestions for school. The school should continue to make improvements, improvements and development of existing school programs, and continue to maintain their commitment to pay attention to the overall development of students, both in terms of spiritual, intellectual, social, emotional, or physical. The division of trust between the trustee and the teacher should be separated, so that each person can be maximal in his work. 
Parents should welcome, support and participate in the success of school programs and targets, and pay more attention and understand the development of children. To all student of Madrasah Aliyah Negeri 1 Surakarta Religious Programs should receive and respond well to every program implemented in the school, and play an active role in these programs.

\section{REFERENCES}

Abdullah., Ridwan., \& Muhammad. (2016). Pendidikan Karakter Mengembangkan Karakter Anak yang Islami. Jakarta: Bumi Aksara.

Abidin, Zainal. (2014). "Konsep Pendidikan Karakter Islam Menurut Ibnu Maskawaih dan Implikasinya Bagi Pendidikan Karakter di Indonesia." Jurnal TAPIS 14, No. 2 , $1-13$.

Ahsanulhaq, Moh. (2019). "Membentuk Karakter Religius Peserta Didik Melalui Metode Pembiasaan." Jurnal Prakarsa Paedagogia 2, No. 1.

Al Syarif., Sarto., \& F, M, Manshur. (2017). "Metode Pendidikan Profetik dalam AlQur'an: Kajian Ayat-ayat Kisah Nabi Ibrahim AS.” Jurnal Penelitian Pendidikan Islam 5, No. 1.

Alam, N, A, R. (2020). "Religious Education Practices in Pesantren: Charismatic Kyai Leadership in Academic and Social Activities." Jurnal Pendidikan Agama Islam (Journal of Islamic Education Studies) 8, no. 2, 195-212.

Alwi, B. M. (2014). Pendidikan Karakter: Solusi Bijak Menyikapi Perilaku Menyimpang Anak. Makasar: Alauddin University Press.

Arifin, M. (2000). Ilmu Pendidikan Islam: Suatu Tinjauan Teortis dan Praktis Berdasarkan Pendekatan Interdisipliner. Jakarta: Bumi Aksara.

Arifin, Zaenal. Implementasi, Pendidikan Karakter, Islami Pada Ekstrakurikuler "Hizbul Wathan". Surakarta: Universitas Muhammadiyah Surakarta.

Budiman, M, N, \& Idris, Saifullah. (2018). "Between Religion and Education in Freud Perspective." Advanced Science Letters 24, no. 10.

Cornelissen, Joep P., dkk. (2020). "Building character: The formation of a hybrid organizational identity in a social enterprise." Journal of Management Studies.

Fauzan, H. A. (2013). “Pendidikan Karakter Religius Bagi Siswa Berasrama Di Smk Negeri 1 Punggelan Banjarnegara”. Skripsi., IAIN Purwokerto. 
Febriandika, N. R., \& Gaida, S. (2021). "Role-Playing Method In Developing Islamic Student's Entrepreneurship Mentality." IQTISHADUNA: Jurnal Ilmiah Ekonomi Kita, 10(1), 32-47.

Fitria, H., Kristiawan, M., \& Rasyid, A. (2019): "The Educational Character on Instruction." Opción 35, 964-979.

Hamalik, Oemar. (2009). Psikologi Belajar Mengajar. Bandung: Sinar Baru Algesindo.

Husni, H. (2020). "Character education in Indonesia: a historical outlook." Educational Review: International Journal 17, no.1, 147-162.

Hussin, N, H., \& Tamuri, A, H. (2019). "Embedding values in teaching Islamic education among excellent teachers." Journal for Multicultural Education 13, no.1, 2-18.

Ilyasin, Mukhamad. (2020). "Transformation of Learning Management: Integrative Study of Islamic Boarding School Curriculum." Dinamika Ilmu 20, no. 1, 13-22.

Johansyah. (2011). "Pendidikan Karakter Dalam Islam Kajian dari Aspek Metodologi.” Jurnal Pendidikan Agama Islam 1, no. 2.

Kamenez, Natalia V., dkk. (2018). "Experience of the use of electronic training in the educational process of the Russian higher educational institution." International Journal of Engineering and Technology (UAE) 7, no. 4, 4085-4089.

Komara, Endang. (2017). "Curriculum and Civic Education Teaching in Indonesia." EDUCARE 10, no. 1, 23-32.

Krettenauer, Tobias. (2021). "Moral sciences and the role of education." Journal of Moral Education 50, no. 1, 77-91.

Muhsinin. (2017). "Model Pendidikan Karakter Berbasis Nilai-Nilai Islam Untuk Membentuk Karakter Siswa Yang Toleran." Jurnal Pendidikan 2, no. 1.

Munawaroh, Azizah. (2019). "Keteladanan Sebagai Metode Pendidikan Karakter.” Jurnal Penelitian Pendidikan Islam 7, no. 2.

Nata, Abuddin. (2012). Kapita Selekta Pendidikan Islam Isu-Isu Kontemporer tentang Pendidikan Islam. Depok: Raja Grafindo Persada.

Prasodjo. (1974). Profil Pesantren. Jakarta: LP3ES.

Sahlan, Asmaun. (2009). Mewujudkan Budaya Religius di Sekolah. Malang: UIN-MALIKI PRESS.

Sanusi, Uci. (2013). “Pendidikan Kemandirian Di Pondok Pesantren.” Jurnal Pendidikan Agama Islam-Ta'lim 10, no. 2. 
28 | Nur Rizqi Febriandika \& Chori Miftahul Kosidatul Natus

Setiawati, A. N. (2017). "Pendidikan Karakter Sebagai Pilar Pembentukan Karakter Bangsa." Jurnal Fakultas Ilmu Sosial Universitas Negeri Medan 1, no. 1.

Suyadi. (2016). Strategi Pembelajaran Pendidikan Karakter. Bandung: Remaja Rosdakarya, 2013.

Tambak, Syahraini. "Metode Bercerita dalam Pembelajaran Pendidikan Agama Islam". Jurnal Al-Thariqah 1, no. 1.

Utaminingsih, S., dkk. (2017). "Strengthening of Indonesian Islamic Character Though Islamic Education Management Based of Soft Skills." Addin 11, no. 1, 215-242.

Wati, Setio. (2017). "Sosialisasi Pendidikan Asrama Sebagai Pembentukan Karakter Siswa Pada Al-Ihsan Boarding School." Jurnal Pendidikan 14, no. 2.

Zakaria, G, A, N. (2010). "Pondok Pesantren: Changes and Its Future." Journal of Islamic and Arabic Education 2, no. 2, 45-52. 